\title{
Comparative Assessment of Antimicrobial Efficiency of Ionic Silver, Silver Monoxide, and Metallic Silver Incorporated onto an Aluminum Oxide Nanopowder Carrier
}

\author{
Agnieszka Maria Jastrzębska, ${ }^{1}$ Ewa Karwowska, ${ }^{2}$ \\ Andrzej R. Olszyna, ${ }^{1}$ and Antoni R. Kunicki ${ }^{3}$ \\ ${ }^{1}$ Faculty of Materials Science and Engineering, Warsaw University of Technology, Woloska 141, 02-507 Warsaw, Poland \\ ${ }^{2}$ Faculty of Environmental Engineering, Warsaw University of Technology, Poland \\ ${ }^{3}$ Faculty of Chemistry, Warsaw University of Technology, Noakowskiego 3, 00-664 Warsaw, Poland \\ Correspondence should be addressed to Agnieszka Maria Jastrzębska; agsolgala@gmail.com
}

Received 11 April 2013; Revised 17 June 2013; Accepted 17 June 2013

Academic Editor: Kalimuthu Kalishwaralal

Copyright (C) 2013 Agnieszka Maria Jastrzębska et al. This is an open access article distributed under the Creative Commons Attribution License, which permits unrestricted use, distribution, and reproduction in any medium, provided the original work is properly cited.

\begin{abstract}
The present paper provides comparative assessment of antimicrobial efficiency of ionic silver $\left(\mathrm{Ag}^{+}\right)$, silver monoxide $\left(\mathrm{Ag}_{2} \mathrm{O}\right)$, and metallic silver $(\mathrm{Ag})$ incorporated onto an aluminum oxide nanopowder carrier $\left(\mathrm{Al}_{2} \mathrm{O}_{3}\right)$. The deposition of $\mathrm{Ag}^{+}$ions, $\mathrm{Ag}_{2} \mathrm{O}$ nanoparticles, and $\mathrm{Ag}$ nanoparticles on an different phases of aluminum oxide nanopowder carrier was realized using consecutive stages of dry sol-gel method. The $\mathrm{Al}_{2} \mathrm{O}_{3}-\mathrm{Ag}^{+}, \mathrm{Al}_{2} \mathrm{O}_{3}-\mathrm{Ag}_{2} \mathrm{O}$, and $\mathrm{Al}_{2} \mathrm{O}_{3}-\mathrm{Ag}$ nanopowders were widely characterized qualitatively and quantitatively by SEM, physical nitrogen sorption and XRD analyses. Results indicate that the $\mathrm{Al}_{2} \mathrm{O}_{3}$ nanopowders added with $\mathrm{Ag}^{+}$, $\mathrm{Ag}_{2} \mathrm{O}$, and $\mathrm{Ag}$, apart from phase composition, were not differing considerably from one another in terms of their morphology and physical properties. However, nanopowders of $\mathrm{Al}_{2} \mathrm{O}_{3}$ - $\mathrm{Ag}$ were more agglomerated than $\mathrm{Al}_{2} \mathrm{O}_{3}-\mathrm{Ag}_{2} \mathrm{O}$ and $\mathrm{Al}_{2} \mathrm{O}_{3}-\mathrm{Ag}^{+}$nanopowders. The antibacterial activity of the nanopowders was examined by the spread plate method using bacterial strains such as Escherichia coli, Sarcina lutea, and Bacillus subtilis. The best antibacterial properties against Sarcina lutea strain were achieved in the amorphous$\mathrm{Al}_{2} \mathrm{O}_{3}-\mathrm{Ag}^{+}$and $\mathrm{Al}_{2} \mathrm{O}_{3}-\mathrm{Ag}_{2} \mathrm{O}$ nanopowders, whereas the worst antimicrobial activity against Bacillus subtilis and Escherichia coli was shown by the $\mathrm{Al}_{2} \mathrm{O}_{3}-\mathrm{Ag}^{+}$and $\mathrm{Al}_{2} \mathrm{O}_{3}-\mathrm{Ag}$ nanopowders. The observed increase of the antibacterial activity as the silver content was not however significant for $\mathrm{Al}_{2} \mathrm{O}_{3}$ - $\mathrm{Ag}$ nanopowders. The results obtained in the present experiments show that the $\mathrm{Al}_{2} \mathrm{O}_{3}-\mathrm{Ag}^{+}$, $\mathrm{Al}_{2} \mathrm{O}_{3}-\mathrm{Ag}_{2} \mathrm{O}$, and $\mathrm{Al}_{2} \mathrm{O}_{3}$-Ag nanopowders, possessing good bactericidal properties, can be produced by using consecutive stages of dry sol-gel method, and $\mathrm{Al}_{2} \mathrm{O}_{3}$ nanopowder added with $\mathrm{Ag}_{2} \mathrm{O}$ is considered as the best raw material in the production of antiseptic materials.
\end{abstract}

\section{Introduction}

At present, there is great demand from the industry for materials that show biocidal properties. That is why, since several years, many research centers all over the world have focused their interest on different forms of silver, mainly metallic silver nanoparticles. Because of their small size, the silver nanoparticles show high-chemical activity dependent on both their sizes and shapes [1]. They have also good antirheumatic [2] and antiinflammatory [3] properties. Results also indicate that the bactericidal effect of the $\mathrm{Ag}$ nanoparticles was a synergic action of Reactive Oxygen Species (ROS) and $\mathrm{Ag}^{+}$, not an additive one [4].

However, unbound silver particles can easily be removed from the carrier material during exploitation. An additional problem is the natural liability of silver nanoparticles to agglomeration, which results in loss of their biological activity. It is therefore necessary that silver should be built onto the surface of the carrier material. Currently, ionic $\mathrm{Ag}^{+}$as well as $\mathrm{Ag}_{2} \mathrm{O}$ and $\mathrm{Ag}$ nanoparticles are considered to be an advantageous addition to matrices of various types $[5,6]$. Their more important recent applications include dressing 
materials [7], packaging materials [6] glass-ceramic coatings [8], coatings on implants [9], filtration membranes [10], and antifouling coatings [10]. However, among many known inert carriers, the most promising material is aluminum nanooxide. It is most often used in the form of shaped porous pieces [11], microspheres [12], or nanoneedles [7]. Microbiological investigation results indicate that $\mathrm{AgCO} / \mathrm{Al}_{2} \mathrm{O}_{3}$ [7], $\mathrm{AgCl} / \mathrm{Al}_{2} \mathrm{O}_{3}$, and $\mathrm{Ag} / \mathrm{Al}_{2} \mathrm{O}_{3}$ [13] exhibit high bactericidal activity at room temperature with no need for any light or electrical power input [13]. In our earlier work, we have used the particles of aluminum oxide as the carrier for silver nanoparticles [14]. Our investigation results have also shown that the $\gamma-\mathrm{Al}_{2} \mathrm{O}_{3}$ - $\mathrm{Ag}$ nanopowders exhibit large specific surface area and good antimicrobial properties $[14,15]$.

However according to above mentioned literature data, there is an evident lack of scientists' unanimity in the comparison of the antibacterial properties of different forms of silver to pathogenic bacteria. This is due to the fact that they are acquired by using various synthesis procedures and methods, which result in different morphology and physical properties of the resulting material, making the ability of their antimicrobial properties comparison impossible.

The present paper provides a comparative assessment of antimicrobial efficiency of ionic silver $\left(\mathrm{Ag}^{+}\right)$, silver monoxide $\left(\mathrm{Ag}_{2} \mathrm{O}\right)$, and metallic silver $(\mathrm{Ag})$ incorporated onto an aluminum oxide nanopowder carrier $\left(\mathrm{Al}_{2} \mathrm{O}_{3}\right)$ in the amorphous form or gamma and eta form. To obtain the above-mentioned nanoparticles possessing similar morphology and physical properties, we have decided to use consecutive stages of the dry sol-gel method [16]. According to our best knowledge, this method has been used for the first time for such a purpose. The dry sol-gel method has been also chosen by us because it is considered to be much more "clean" from the chemical point of view, since during this process, apart from carbon dioxide, no other undesired side products appear which could be harmful to the environment [14]. It also enables acquiring ionic silver $\left(\mathrm{Ag}^{+}\right)$, silver monoxide $\left(\mathrm{Ag}_{2} \mathrm{O}\right)$, and metallic silver $(\mathrm{Ag})$ deposited on an aluminum oxide nanopowder carrier. This can be easily done by using consecutive stages of this process.

\section{Materials and Methods}

2.1. Techniques for $\mathrm{Al}_{2} \mathrm{O}_{3}-\mathrm{Ag}^{+}, \mathrm{Al}_{2} \mathrm{O}_{3}-\mathrm{Ag}_{2} \mathrm{O}$, and $\mathrm{Al}_{2} \mathrm{O}_{3}-\mathrm{Ag}$ Nanopowders Synthesis. Ionic silver $\left(\mathrm{Ag}^{+}\right)$, silver monoxide $\left(\mathrm{Ag}_{2} \mathrm{O}\right)$, and metallic silver $(\mathrm{Ag})$ were deposited on an aluminum oxide nanopowder carrier by using consecutive stages of dry sol-gel method. A flow chart of the processes used in the present study is shown in Figure 1 and its detailed description is given below. All the reagents were delivered by the Sigma Aldrich Co. and were used in the delivery state.

Dry sol-gel method consists of a mild reaction between a mixture of a metal-organic aluminum compound (triethylaluminium- $\mathrm{Et}_{3} \mathrm{Al}$ ) and alumoxan (aluminum triisopropoxide $\left.(i-\mathrm{PrO})_{3} \mathrm{Al}\right)$ with oxygen from the air. The reaction was conducted in an organic solvent (hexane). The reagents were added in such amounts that the concentration of the aluminum compounds was $0.1 \mathrm{M}$. The silver benzoate was then added to reactive mixture so that the silver content in the final product was $0.0,0.30,1.35,2.84$, and $12.55 \mathrm{wt} \%$. Subsequently, solvent was removed and resulting powder was dried in air at $25^{\circ} \mathrm{C}, 24 \mathrm{~h}$. This process gave ionic silver deposited on amorphous aluminum nanooxide carrier $\left(\mathrm{Al}_{2} \mathrm{O}_{3}-\mathrm{Ag}^{+}\right)$(1). Precursor was then subjected to thermal decomposition in air at $700^{\circ} \mathrm{C}$ for $24 \mathrm{~h}$ in a muffle furnace. This process gave single-valent silver oxide nanoparticles deposited on aluminum nanooxide carrier $\left(\mathrm{Al}_{2} \mathrm{O}_{3}-\mathrm{Ag}_{2} \mathrm{O}\right)$ (2). The intermediary product thus obtained was subjected to reduction in a hydrogen atmosphere at $700^{\circ} \mathrm{C}$ for $2 \mathrm{~h}$, which yielded the final product, that is, the $\mathrm{Al}_{2} \mathrm{O}_{3}-\mathrm{Ag}$ nanopowder (3). The reactions described above are described by the formulae

$$
\begin{array}{r}
(i-\mathrm{PrO})_{3} \mathrm{Al}+\mathrm{Et}_{3} \mathrm{Al} \stackrel{\mathrm{O}_{2}, \mathrm{C}_{6} \mathrm{H}_{14}, \mathrm{C}_{7} \mathrm{H}_{5} \mathrm{COO}^{-} \mathrm{Ag}^{+} \text {,drying }}{\longrightarrow} \\
\mathrm{Al}_{2} \mathrm{O}_{3}-\mathrm{C}_{7} \mathrm{H}_{5} \mathrm{COO}^{-} \mathrm{Ag}^{+} \\
\mathrm{Al}_{2} \mathrm{O}_{3}-\mathrm{C}_{7} \mathrm{H}_{5} \mathrm{COO}^{-} \mathrm{Ag}^{+} \stackrel{\mathrm{O}_{2}, 700^{\circ} \mathrm{C}, 24 \mathrm{~h}}{\longrightarrow} \\
\mathrm{Al}_{2} \mathrm{O}_{3}-\mathrm{Ag}_{2} \mathrm{O} \\
+\mathrm{CO}_{2}+\mathrm{H}_{2} \mathrm{O} \\
\mathrm{Al}_{2} \mathrm{O}_{3}-\mathrm{Ag}_{2} \mathrm{O} \stackrel{\mathrm{H}_{2}, 700^{\circ} \mathrm{C}, 2 \mathrm{~h}}{\longrightarrow} \mathrm{Al}_{2} \mathrm{O}_{3}-\mathrm{Ag}+\mathrm{H}_{2} \mathrm{O}
\end{array}
$$

2.2. Experimental Procedure. The phase composition of the nanopowders was examined with an X-ray diffractometer (XRD-Philips 1830) using a copper lamp radiation $(\mathrm{CuK} \alpha)$. A qualitative phase analysis was based on the data recorded within the $2 \theta$ angle range from $20^{\circ}$ to $120^{\circ}$ at a $2 \theta$ increment of $0.05^{\circ}$ and a counting time of $3 \mathrm{~s}$.

The morphology of the nanopowders was examined in a scanning electron microscope (SEM-LEO 1530, Zeiss) operated at an accelerating voltage of $2.0 \mathrm{kV}$. The test nanopowder samples were prepared according to the following procedure. After preparing a mixture of the nanopowder in propan-2-ol using an ultrasonic homogenizer for $1 \mathrm{~min}$, a drop of it was placed, with a pipette, on a polished thin monolithic silicon plates. Then, the surface of each of the plates was dried, and the deposited nanopowders were coated with a thin carbon layer using a BAL-TEC SCD 005 duster equipped with a CEA 035 unit.

The microscopic examinations were also aimed at characterising quantitatively the nanopowders by the so-called stereological analysis using a MicroMeter v.086b computer program designed for analysing and processing the images of microstructures. The stereological analysis of the nanopowders also utilized the SEM images. The stereological parameters were measured on the individual cross sections of the nanopowder particles and then; the average value of a given parameter $d_{2}$ was calculated. The calculated value of the average size $\overline{d_{2}}$ of a particle or agglomerate, also called the equivalent diameter, is defined as the diameter of a circle with the surface area equal to that of the analyzed particle or agglomerate. The analysis also took into account the coefficient of variation $\mathrm{CV}\left(d_{2}\right)$ of the measured values with a parameter $n=327$ for particles and $n=121$ for agglomerates statistical analysis. 


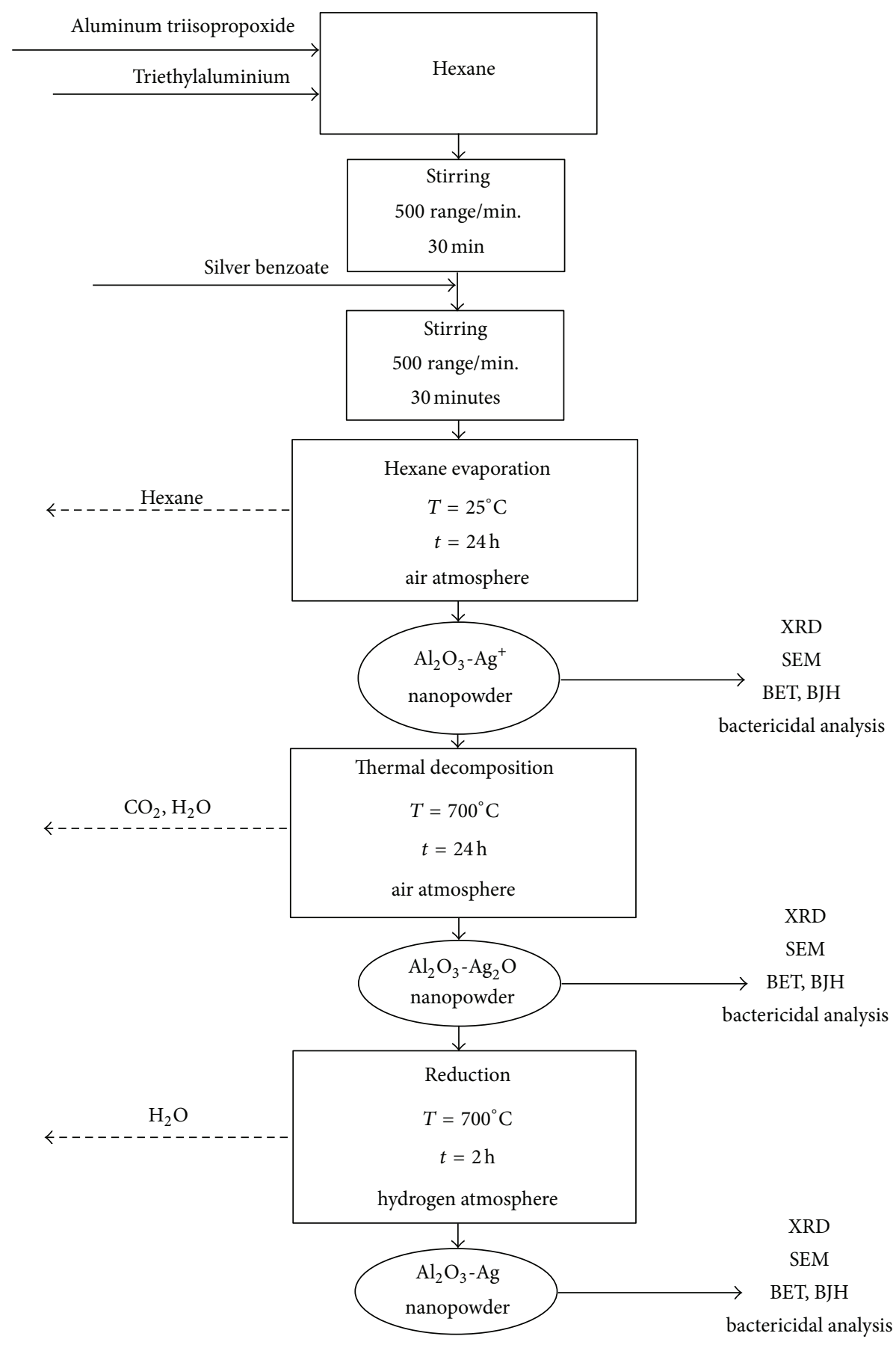

Figure 1: Flow chart of the $\mathrm{Al}_{2} \mathrm{O}_{3}-\mathrm{Ag}^{+}, \mathrm{Al}_{2} \mathrm{O}_{3}-\mathrm{Ag}_{2} \mathrm{O}$, and $\mathrm{Al}_{2} \mathrm{O}_{3}-\mathrm{Ag}$ nanopowders synthesis process as well as methods of analyzes.

The specific surface area of the nanopowders was examined based on the isotherms of the physical nitrogen adsorption measured experimentally, using a Quadrasorb-SI device (Quantachrome Co). Before the measurements, the samples were degassed at a temperature of $350^{\circ} \mathrm{C}$ for $48 \mathrm{~h}$. The adsorption and desorption of nitrogen on the surface of the nanoparticles were measured at a temperature of $-195.8^{\circ} \mathrm{C}$, within the entire range of the relative pressure. The specific surface area $S_{\mathrm{BET}}$ was determined using the Brunauer,
Emmett, Teller, method and the BET equation, which permit determining the specific surface area within the range of the relative pressure $P P_{0}^{-1}$ from 0.05 to 0.35 .

The total volume of the pores present in the nanopowders, $V_{\mathrm{BJH}}$, was determined by the Barret, Joyner, and Halenda method and using the $\mathrm{BJH}$ equation based on the isotherms of the physical desorption of nitrogen. The assumption underlying this method is that during the capillary condensation at the relative pressure below 0.4 , the only effect which 
occurs with a further increase of the pressure is the thickening of the mono-layer of the adsorbate formed on the surface of the pore walls. The distributions of the pore sizes determined by the $\mathrm{BJH}$ method were used for estimating the average pore size $D_{\mathrm{BJH}}$.

Finally, the bactericidal activity of the $\mathrm{Al}_{2} \mathrm{O}_{3}-\mathrm{Ag}$ powders was examined by the spread plate method. The microorganisms examined in the present experiments came from the private collection of Biology Department, Faculty of Environmental Engineering, Warsaw University of Technology, and included bacteria strains such as Escherichia coli, Sarcina lutea, and Bacillus subtilis. The bacteria strains were inoculated on a nutrient agar medium (delivered by the MERCK), appropriately prepared and sterilized, which was deposited in Petri plates. The inoculation was performed using a sterile glass rod. The bacteria were spread on the surface of the nutrient medium, where an appropriate powder was then deposited. The growth inhibition zone of each bacterial strain was determined after incubation at a temperature of $37^{\circ} \mathrm{C}$ (Escherichia coli) or $26^{\circ} \mathrm{C}$ (other bacterial cultures) for $72 \mathrm{~h}$. Subsequently, photographic documentation of the Petri plates was performed. Because the nanopowders were not regularly distributed (the area occupied by each of the nanopowders was not $6.35 \mathrm{~mm}$ standardized width according to Kirby-Bauer method) [17], antimicrobial efficiencies of nanopowders were assessed by means of the Kirby-Bauer method, adjusted to the analysis of the nanopowders. The relative bacterial inhibition zone $D_{\mathrm{K}-\mathrm{B}}$ was determined by using equation

$$
D_{\mathrm{K}-\mathrm{B}}=\frac{6,35 \cdot D_{1}}{D_{2}} \text {, }
$$

where 6,35 is a standardized width of a Kirby-Bauer paper $\operatorname{disc}(\mathrm{mm}), D_{1}$ is the width of a bacterial inhibition zone $(\mathrm{mm})$ and $D_{1}=\left(D_{1 a}+D_{1 b}+\cdots+D_{1 h}\right) / 8, D_{2}$ is the width of a zone occupied by the nanopowder $(\mathrm{mm})$ and $D_{2}=\left(D_{2 a}+D_{2 b}+\cdots\right.$ $\left.\cdot+D_{2 h}\right) / 8$.

Method for determining $D_{1}$ and $D_{2}$ parameters is also presented in Figure 2. The $D_{1}$ parameter represents the inhibition zone (a dark area around a nanopowder) in which the growth of a bacterium susceptible to the powder is inhibited. The size (width) of this zone is proportional to how sensitive the particular microorganism is. The $D_{2}$ parameter represents the width of a zone occupied by the particular nanopowder. It should be however noted that the width of the bacterial inhibition zone is always the same, no matter what amount of zone the particular nanopowder will occupy. Thus, it can be assumed that the width of a bacterial inhibition zone depends only on its antibacterial properties and the concentration of the powder at different measured areas is not significant.

Measurement of each of the parameter was repeated eight times around a circle (Figure 2) and performed by using NIS Elements 3.22.11 (Nikon) computer program designed for photodocumentation analysis and processing. The results were presented in Figure 7 as mean \pm standard deviation.
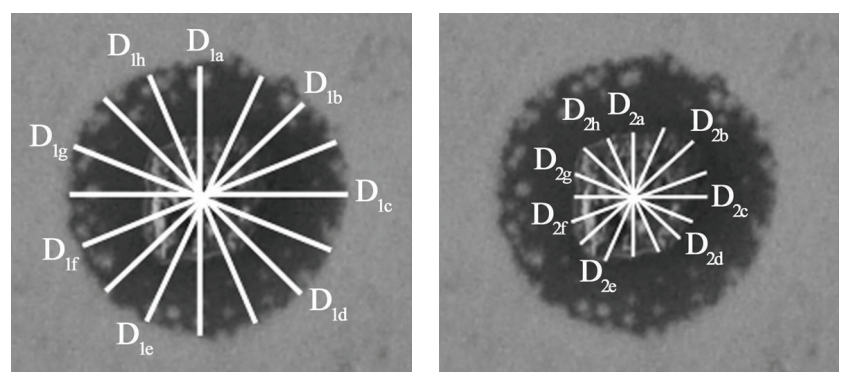

FIGURE 2: Method for determining $D_{1}$ and $D_{2}$ parameters for modified Kirby-Bauer method.

\section{Results}

The phase composition of the nanopowders was examined by X-ray diffractometry. The presence of amorphous aluminium, aluminum oxide, silver monoxide, and metallic silver in the nanopowders was confirmed by XRD examinations. The diffractogram obtained for the $\mathrm{Al}_{2} \mathrm{O}_{3}-\mathrm{Ag}^{+}$ revealed the presence of the amorphous aluminium oxide phase (Figure 3(a)). There was no evidence for any silver phase. It should be however noted that the XRD method is not able to detect organic phases. Thus, the acquired result however confirms the presence of $\mathrm{Ag}^{+}$in the nanopowder. The intermediate product of the synthesis process, obtained after the thermal decomposition process $\left(\mathrm{Al}_{2} \mathrm{O}_{3}-\mathrm{Ag}_{2} \mathrm{O}\right)$, contained gamma and eta aluminium oxide phases and the 1valent silver oxide phase (Figure 3(b)) which then, during the reduction process, was entirely transformed into metallic silver (Figure 3(c)). The final product, that is, the $\mathrm{Al}_{2} \mathrm{O}_{3}-\mathrm{Ag}$ (2.84 wt\%) nanopowder, did not contain the eta phase of aluminum oxide, since it had been entirely transformed into the more stable gamma phase.

However, the silver additive affected the morphology and liability to agglomeration of the resulting nanopowders was analyzed in a scanning electron microscope. By way of example, Figure 4 shows SEM images obtained for the $\mathrm{Al}_{2} \mathrm{O}_{3}-\mathrm{Ag}^{+}, \mathrm{Al}_{2} \mathrm{O}_{3}-\mathrm{Ag}_{2} \mathrm{O}$, and $\mathrm{Al}_{2} \mathrm{O}_{3}-\mathrm{Ag}$ nanopowders. We can see that they contain both agglomerates and single particles. Images also show that, at higher $\mathrm{Ag}^{+}, \mathrm{Ag}_{2} \mathrm{O}$, and Ag contents, nanopowders that have more significant liability to agglomeration and nanopowders added with $\mathrm{Ag}$ are much more agglomerated than those, added with $\mathrm{Ag}^{+}$and $\mathrm{Ag}_{2} \mathrm{O}$.

The SEM images were also used in the stereological analysis. The results are given in Figure 5 and in Tables 1 and 2. Results of the particle stereological analysis (Table 1) show that the average particle sizes of the nanopowders added with $\mathrm{Ag}^{+}, \mathrm{Ag}_{2} \mathrm{O}$, and $\mathrm{Ag}$ does not differ much from each other (Figures 5(a), 5(b) and 5(c)). The range of particle sizes of nanopowders added with $\mathrm{Ag}^{+}$and $\mathrm{Ag}$ is similar to that of pure $\mathrm{Al}_{2} \mathrm{O}_{3}$. However, $\mathrm{Al}_{2} \mathrm{O}_{3}-\mathrm{Ag}_{2} \mathrm{O}$ particle stereological analysis shows that the range of particle sizes of these nanopowders is smaller in comparison with that of pure $\mathrm{Al}_{2} \mathrm{O}_{3}$ (Figure 5(b)). Results of the agglomerate stereological analysis (Table 2) show that at higher $\mathrm{Ag}^{+}$and $\mathrm{Ag}_{2} \mathrm{O}$ contents (Figures 5(a) and $5(\mathrm{~b})$ ), the average agglomerate size does not differ much from that observed in the pure $\mathrm{Al}_{2} \mathrm{O}_{3}$ nanopowder 


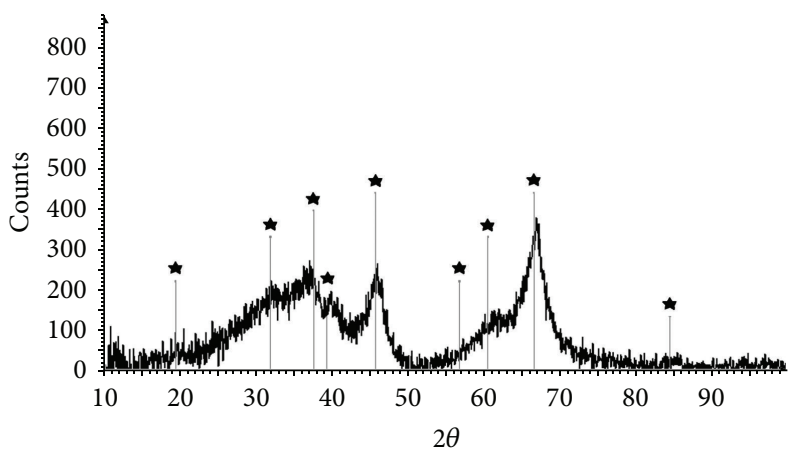

$\star$ 00-050-0741-amorphous $\mathrm{Al}_{2} \mathrm{O}_{3}$

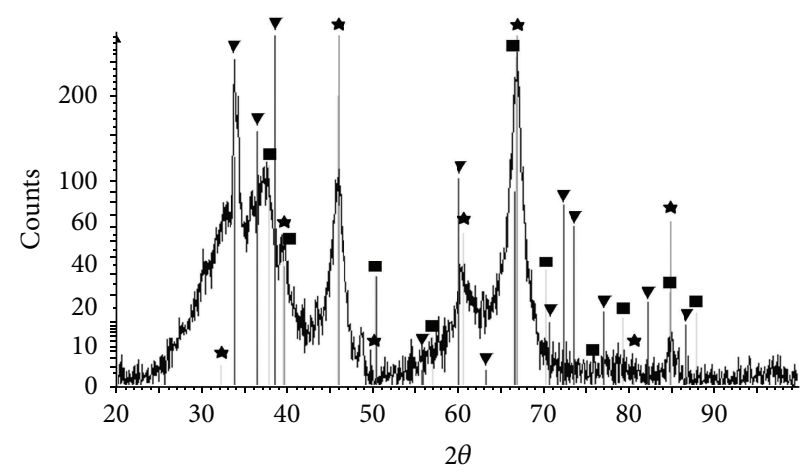

$\star 01-079-1158-\gamma \mathrm{Al}_{2} \mathrm{O}_{3}$

- 01-079-1557- $\eta \mathrm{Al}_{2} \mathrm{O}_{3}$

v 01-072-2108- $\mathrm{Ag}_{2} \mathrm{O}$

(a)

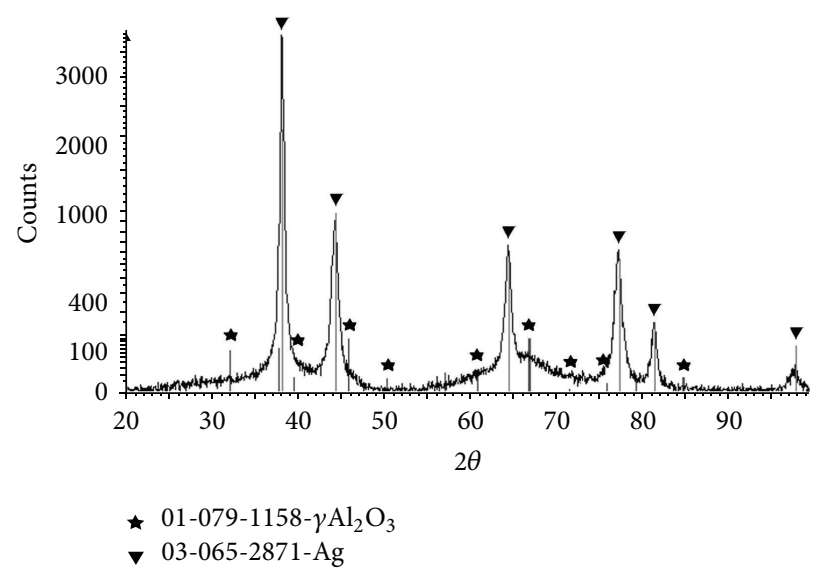

(c)

FIGURE 3: XRD diffractograms obtained for the $\mathrm{Al}_{2} \mathrm{O}_{3}-\mathrm{Ag}^{+}$nanopowder (a), intermediary product after the thermal decomposition conducted at a temperature of $700^{\circ} \mathrm{C}$ for $24 \mathrm{~h}\left(\mathrm{Al}_{2} \mathrm{O}_{3}-\mathrm{Ag}_{2} \mathrm{O}\right)(\mathrm{b})$, and the final product after the reduction process conducted at a temperature of $700^{\circ} \mathrm{C}$ for $2 \mathrm{~h}$ in $\mathrm{H}_{2}\left(\mathrm{Al}_{2} \mathrm{O}_{3}-\mathrm{Ag}\right)(\mathrm{c})$. The final product contained $2.84 \mathrm{wt} \%$ of silver.

$(312 \mathrm{~nm}$, coefficient of variation $=54 \mathrm{~nm})$. It was only with the $\mathrm{Al}_{2} \mathrm{O}_{3}$ - $\mathrm{Ag}$ nanopowders when the concentration of $\mathrm{Ag}$ becomes highly disadvantageous: the particle size increases from $310 \mathrm{~nm}$ (sample 2) to $505 \mathrm{~nm}$ and $962 \mathrm{~nm}$ (samples 3, and 4 , resp.) (Figure 5(c)). Others results also confirm that morphology of the particles plays an important role in silver particles antimicrobial activity. Pal et al. [18] showed that triangular-shaped silver nanoplates displayed the strongest biocidal action against $E$. coli, compared with spherical and rod-shaped nanoparticles and with $\mathrm{Ag}^{+}$ions (in the form of $\mathrm{AgNO}_{3}$ ).

The specific surface area of the $\mathrm{Al}_{2} \mathrm{O}_{2}-\mathrm{Ag}$ nanopowders and their open porosity which characterizes the structure of the nanopowder agglomerates were examined based on the isotherms of nitrogen physical sorption determined experimentally. The results including the specific surface area, the total volume of the pores, and the average pore diameter are given in Table 3 . We can see that the specific surface area of the sample 2 added with $\mathrm{Ag}_{2} \mathrm{O}$ and $\mathrm{Ag}$ exceeds $200 \mathrm{~m}^{2} \mathrm{~g}^{-1}$, with the total pore volume above $1.1 \times 10^{-3} \mathrm{~m}^{3} \mathrm{~g}^{-1}$ and the average pore diameter exceeding $20 \mathrm{~nm}$. The lower specific surface area, below $180 \mathrm{~m}^{2} \mathrm{~g}^{-1}$, was found in the other samples $(0,1,3$ and 4$)$ added with $\mathrm{Ag}_{2} \mathrm{O}$ and $\mathrm{Ag}$ with the total pore volume below $1 \times 10^{3} \mathrm{~m}^{3} \mathrm{~g}^{-1}$. For example, high specific surface area of the $\mathrm{Al}_{2} \mathrm{O}_{3}$ nanopowder (above $250 \mathrm{~m}^{2} \mathrm{~g}^{-1}$ ) indicates that this nanopowder is highly amorphous and that the possible agglomerates have a very loose structure. Our results can be compared with those of Buckley et al. [7] suggesting that the antibacterial performance (against Staphylococcus aureus and Pseudomonas aeruginosa strains) of alumina-supported materials exhibits a striking increase with bacteria inhibition zone size and is directly proportional to the carbonate surface area.

Investigations of the antimicrobial properties of the pure $\mathrm{Al}_{2} \mathrm{O}_{3}$ nanopowder as well as added with $\mathrm{Ag}^{+}, \mathrm{Ag}_{2} \mathrm{O}$ and Ag were performed using the classical culture method. The results of the examination of the antiseptic properties of the nanopowders by means of the culture method as well as relative bacterial growth inhibition zone analysis are shown in Figures 6 and 7. They indicate that the inhibitory effect against 

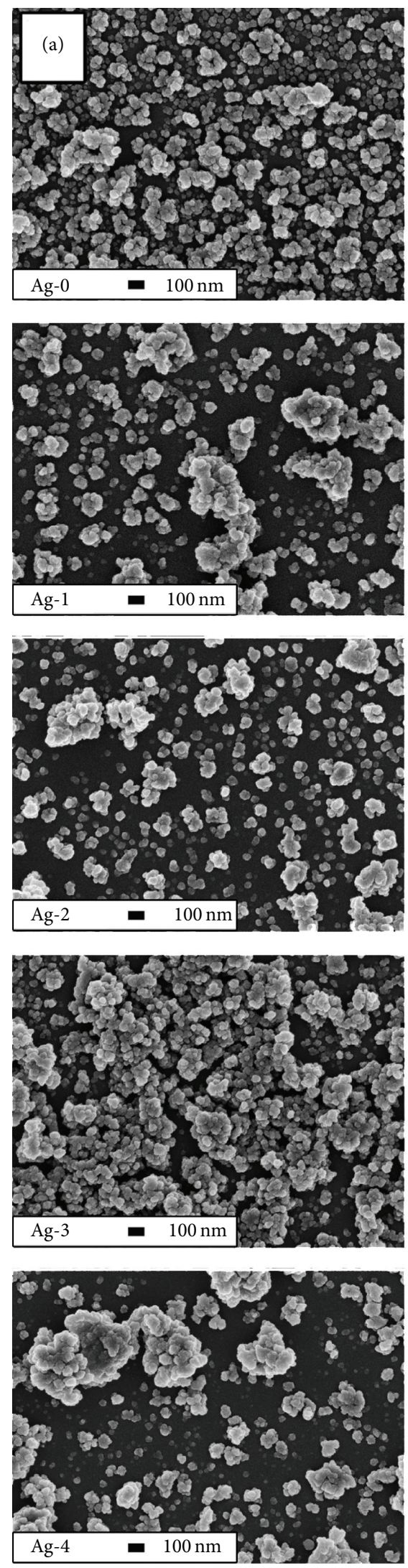
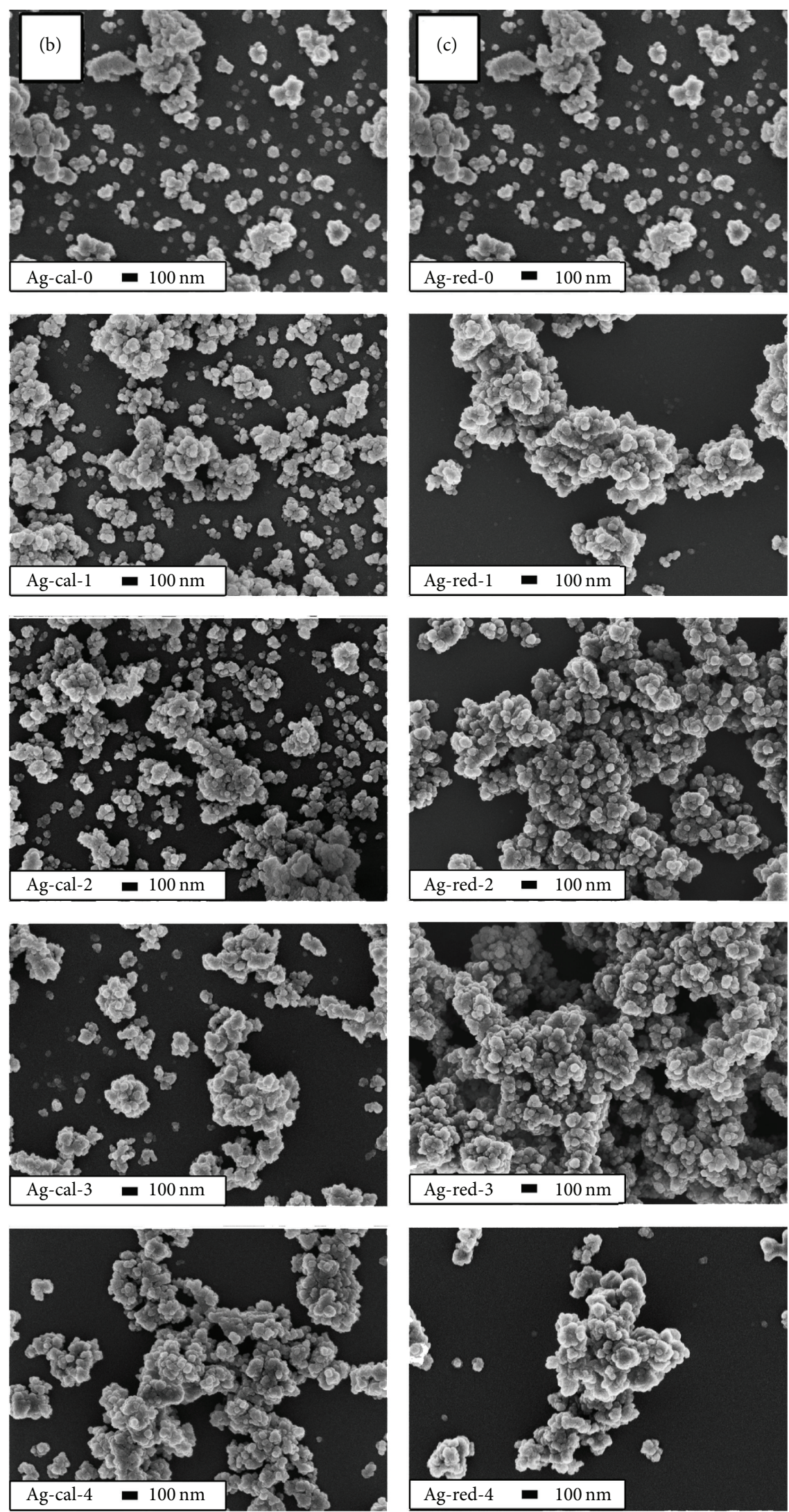

Figure 4: SEM images obtained for the nanopowders such as $\mathrm{Al}_{2} \mathrm{O}_{3}-\mathrm{Ag}^{+}$(a), $\mathrm{Al}_{2} \mathrm{O}_{3}-\mathrm{Ag}_{2} \mathrm{O}$ (b), and $\mathrm{Al}_{2} \mathrm{O}_{3}-\mathrm{Ag}$ (c) produced by using consecutive stages of the dry sol-gel method. The silver content in the final product was $0.0 \mathrm{wt} \%$ (samples marked with 0 ), $0.30 \mathrm{wt} \%$ (samples marked with 1), $1.35 \mathrm{wt} \%$ (samples marked with 2), $2.84 \mathrm{wt} \%$ (samples marked with 3), and $12.55 \mathrm{wt} \%$ (samples marked with 4). 

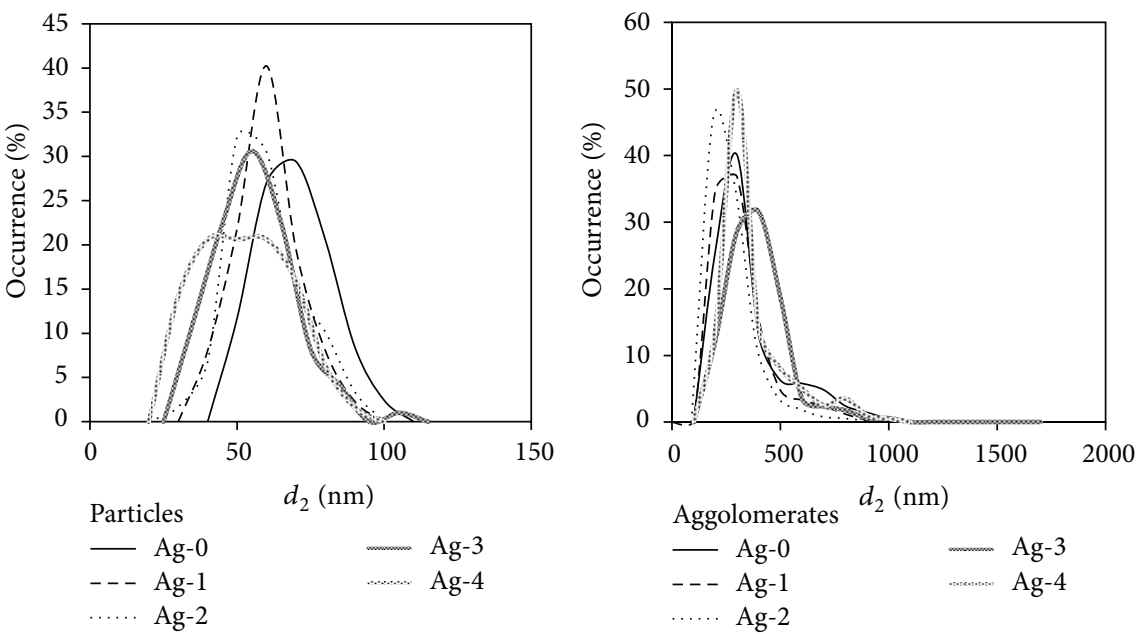

(a)
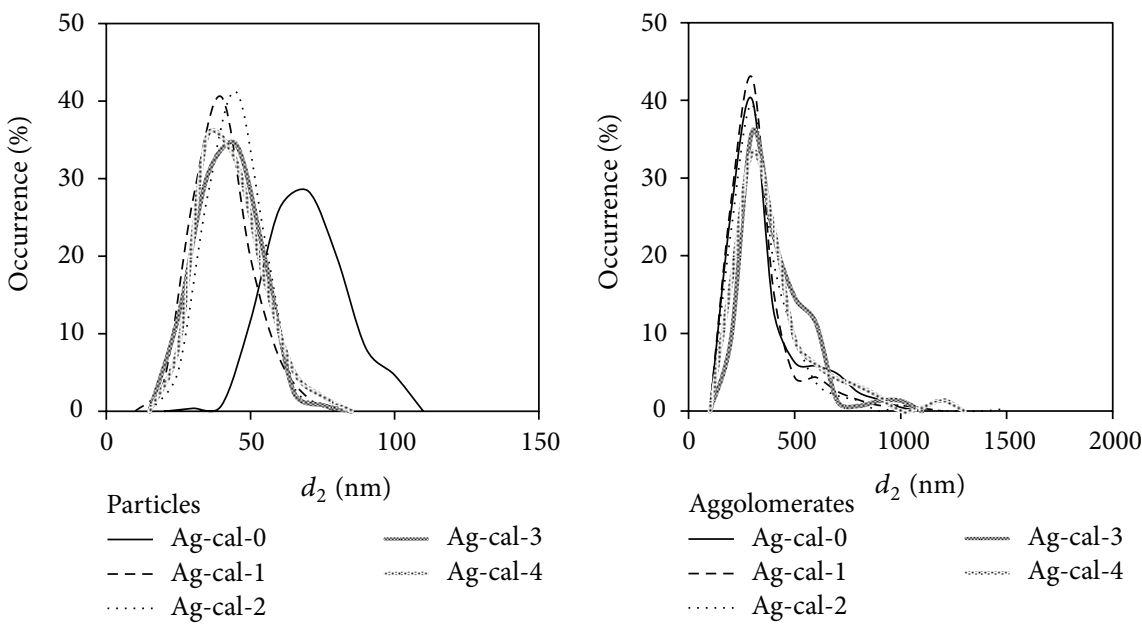

(b)
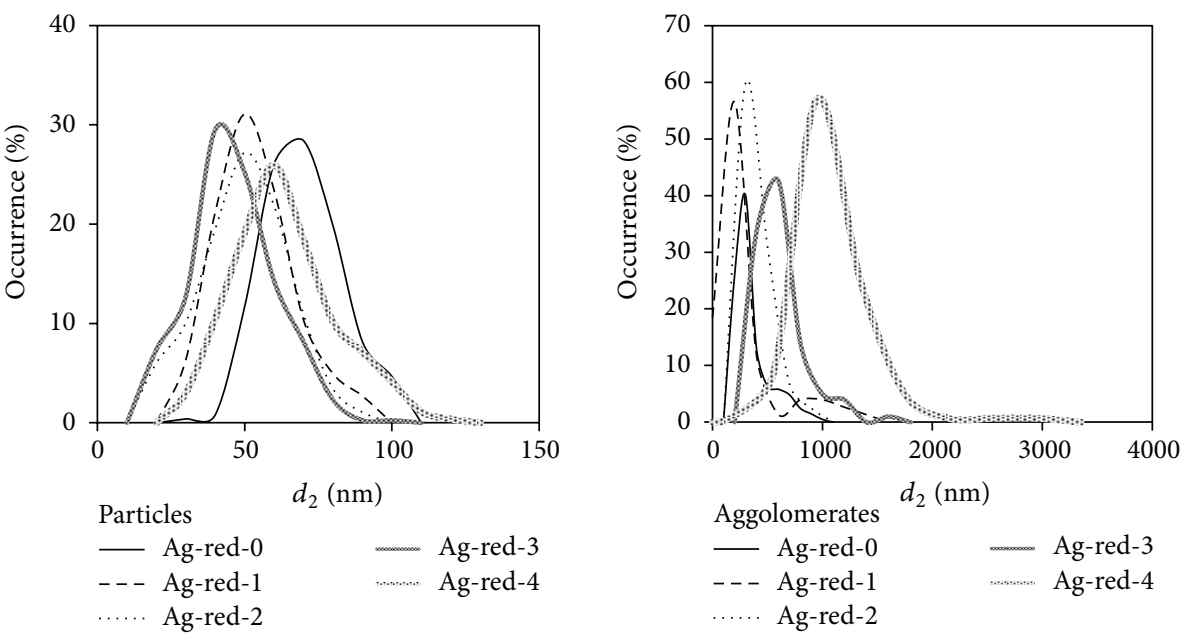

(c)

Figure 5: Particle and agglomerate size distributions of the nanopowders produced by using consecutive stages of the dry sol-gel method such as $\mathrm{Al}_{2} \mathrm{O}_{3}-\mathrm{Ag}^{+}$after hexane evaporation at $25^{\circ} \mathrm{C}, 24 \mathrm{~h}$, air atmosphere (a); $\mathrm{Al}_{2} \mathrm{O}_{3}-\mathrm{Ag}_{2} \mathrm{O}$ after thermal decomposition at $700^{\circ} \mathrm{C}, 24 \mathrm{~h}$, air atmosphere (b); and $\mathrm{Al}_{2} \mathrm{O}_{3}-\mathrm{Ag}$ after reduction at $700^{\circ} \mathrm{C}, 2 \mathrm{~h}, \mathrm{H}_{2}$ atmosphere (c). The silver content in the final product was $0.0 \mathrm{wt} \%$ (samples marked with 0), $0.30 \mathrm{wt} \%$ (samples marked with 1), $1.35 \mathrm{wt} \%$ (samples marked with 2), $2.84 \mathrm{wt} \%$ (samples marked with 3 ), and $12.55 \mathrm{wt} \%$ (samples marked with 4). 
TABLE 1: Results of the particle stereological analysis of the $\mathrm{Al}_{2} \mathrm{O}_{3}-\mathrm{Ag}^{+}, \mathrm{Al}_{2} \mathrm{O}_{3}-\mathrm{Ag}_{2} \mathrm{O}$, and $\mathrm{Al}_{2} \mathrm{O}_{3}-\mathrm{Ag}$ nanopowders produced by thermal decomposition at $700^{\circ} \mathrm{C}$ for $24 \mathrm{~h}$ followed by reduction in $\mathrm{H}_{2}$ conducted at $700^{\circ} \mathrm{C}$ for $2 \mathrm{~h}$.

\begin{tabular}{|c|c|c|c|c|c|c|}
\hline \multirow{2}{*}{$\begin{array}{l}\text { Sample numbers } \\
\text { (Ag concentration) }\end{array}$} & \multicolumn{2}{|c|}{$\mathrm{Al}_{2} \mathrm{O}_{3}-\mathrm{Ag}^{+}$particle } & \multicolumn{2}{|c|}{$\mathrm{Al}_{2} \mathrm{O}_{3}-\mathrm{Ag}_{2} \mathrm{O}$ particle } & \multicolumn{2}{|c|}{$\mathrm{Al}_{2} \mathrm{O}_{3}$-Ag particle } \\
\hline & $\overline{d_{2}} / \mathrm{nm}$ & $\operatorname{CV}\left(d_{2}\right) /[\%]$ & $\overline{d_{2}} / \mathrm{nm}$ & $\operatorname{CV}\left(d_{2}\right) /[\%]$ & $\overline{d_{2}} / \mathrm{nm}$ & $\mathrm{CV}\left(d_{2}\right) /[\%]$ \\
\hline $0(0.00 \mathrm{wt} \%)$ & 65 & 18 & 65 & 20 & - & - \\
\hline $1(0.30 \mathrm{wt} \%)$ & 55 & 20 & 35 & 28 & 49 & 28 \\
\hline $2(1.35 \mathrm{wt} \%)$ & 54 & 23 & 39 & 23 & 45 & 34 \\
\hline $3(2.84 \mathrm{wt} \%)$ & 51 & 26 & 37 & 27 & 41 & 36 \\
\hline 4 (12.55 wt\%) & 48 & 32 & 38 & 30 & 59 & 30 \\
\hline
\end{tabular}

TABLE 2: Results of the agglomerate stereological analysis of the $\mathrm{Al}_{2} \mathrm{O}_{3}-\mathrm{Ag}^{+}, \mathrm{Al}_{2} \mathrm{O}_{3}-\mathrm{Ag}_{2} \mathrm{O}$, and $\mathrm{Al}_{2} \mathrm{O}_{3}-\mathrm{Ag}$ nanopowders produced by thermal decomposition at $700^{\circ} \mathrm{C}$ for $24 \mathrm{~h}$ followed by reduction in $\mathrm{H}_{2}$ conducted at $700^{\circ} \mathrm{C}$ for $2 \mathrm{~h}$.

\begin{tabular}{|c|c|c|c|c|c|c|}
\hline \multirow{2}{*}{$\begin{array}{l}\text { Sample numbers } \\
\text { (Ag concentration) }\end{array}$} & \multicolumn{2}{|c|}{$\mathrm{Al}_{2} \mathrm{O}_{3}-\mathrm{Ag}^{+}$agglomerate } & \multicolumn{2}{|c|}{$\mathrm{Al}_{2} \mathrm{O}_{3}-\mathrm{Ag}_{2} \mathrm{O}$ agglomerate } & \multicolumn{2}{|c|}{$\mathrm{Al}_{2} \mathrm{O}_{3}-\mathrm{Ag}$ agglomerate } \\
\hline & $\overline{d_{2}} / \mathrm{nm}$ & $\mathrm{CV}\left(d_{2}\right) /[\%]$ & $\overline{d_{2}} / \mathrm{nm}$ & $\mathrm{CV}\left(d_{2}\right) /[\%]$ & $\overline{d_{2}} / \mathrm{nm}$ & $\mathrm{CV}\left(d_{2}\right) /[\%]$ \\
\hline $0(0.00 \mathrm{wt} \%)$ & 312 & 54 & 312 & 54 & - & - \\
\hline $1(0.30 \mathrm{wt} \%)$ & 270 & 54 & 291 & 53 & 388 & 73 \\
\hline $2(1.35 \mathrm{wt} \%)$ & 226 & 51 & 302 & 50 & 310 & 43 \\
\hline $3(2.84 \mathrm{wt} \%)$ & 344 & 40 & 370 & 57 & 505 & 44 \\
\hline $4(12.55 \mathrm{wt} \%)$ & 336 & 62 & 356 & 54 & 962 & 63 \\
\hline
\end{tabular}

the individual bacterial strains varied greatly depending on the composition of the nanopowder and it was enhanced with increasing silver content. Figure 6 shows exemplary photographs of the Petri plates covered with pure $\mathrm{Al}_{2} \mathrm{O}_{3}$ and $\mathrm{Al}_{2} \mathrm{O}_{3}-\mathrm{Ag}^{+}, \mathrm{Ag}_{2} \mathrm{O}$, and $\mathrm{Ag}$ nanopowders. Dark areas (inhibition zones) visible around the examined nanopowders are evidence that they inhibit the growth of bacteria such as Escherichia coli, Sarcina lutea, and Bacillus subtilis. Results indicate that the bacterial growth inhibition zones only occur on the Petri plates covered with silver-added $\mathrm{Al}_{2} \mathrm{O}_{3}$ nanopowders. No such rings are observed on the surfaces of the Petri plates covered with pure $\mathrm{Al}_{2} \mathrm{O}_{3}$ nanopowder (no silver addition-samples: Ag-0, Ag-cal-0 and Ag-red-0) which itself has evidently no biocidal properties.

Quantitative results of an growth test indicate that the relative bacterial growth inhibition zone does not exceed $12 \mathrm{~mm}$ for nanopowders added with $\mathrm{Ag}^{+}$and $\mathrm{Ag}$ for all examined bacteria (Figure 7). The best antibacterial properties against Sarcina lutea strain were achieved in the $\mathrm{Al}_{2} \mathrm{O}_{3}$ nanopowders added with $\mathrm{Ag}^{+}$and $\mathrm{Ag}_{2} \mathrm{O}$, whereas the lowest effect was observed for Bacillus subtilis and Escherichia coli in case of the $\mathrm{Al}_{2} \mathrm{O}_{3}-\mathrm{Ag}^{+}$and $\mathrm{Al}_{2} \mathrm{O}_{3}-\mathrm{Ag}$ nanopowders. The relative growth inhibition zone for $\mathrm{Al}_{2} \mathrm{O}_{3}-\mathrm{Ag}^{+}$nanopowders exceeded $16.5 \mathrm{~mm}$, showing that the bacteria inhibition was about $100 \%$ better in comparison with $\mathrm{Al}_{2} \mathrm{O}_{3}$ nanopowder. The observed increase of the bactericidal activity, as the silver content was increased, was not however significant for $\mathrm{Al}_{2} \mathrm{O}_{3}-\mathrm{Ag}$ nanopowders. With the nanopowder containing $\mathrm{Ag}^{+}$, no substantial enhancement of the inhibitory effect was observed for Escherichia coli. Further $\mathrm{Ag}^{+}$increase did not improve appreciably the antibacterial effectiveness of the nanopowders. Also Choi et al. [19] based on a prolonged microtiter assay demonstrated that at about $4.2 \mu \mathrm{M} \mathrm{Ag}$, the inhibitions on the growth of Escherichia coli by $\mathrm{Ag}$ nanoparticles, $\mathrm{Ag}^{+}$ions, and $\mathrm{AgCl}$ colloids were about 55\%, $100 \%$, and $66 \%$, respectively. Similar results were obtained by Chang et al. [13]. They investigated the catalytic inactivation of E. coli (E. coli) in water by $\mathrm{Al}_{2} \mathrm{O}_{3}$-Ag and $\mathrm{Al}_{2} \mathrm{O}_{3}$ - $\mathrm{AgCl}$ particles. Their results showed that $\mathrm{Al}_{2} \mathrm{O}_{3}-\mathrm{Ag}$ (at $50 \mathrm{mg} / \mathrm{L}$ ) with the larger amount of eluted $\mathrm{Ag}^{+}$actually exhibited stronger bactericidal activity than $\mathrm{Al}_{2} \mathrm{O}_{3}-\mathrm{AgCl}$, which implied that $\mathrm{Ag}^{+}$may play an important role in the bactericidal process. Our results can be also compared with those of Buckley et al. [7] who investigated the antimicrobial activity of the $\mathrm{Ag} / \mathrm{meso}-\mathrm{Al}_{2} \mathrm{O}_{3}$ by zone plate inhibition method against Staphylococcus aureus and Pseudomonas aeruginosa strains. The normalised zone of inhibition of the supported $\mathrm{Ag}_{2} \mathrm{CO}_{3}$ nanoparticles far exceeded that of bulk $\mathrm{AgO}, \mathrm{Ag}_{2} \mathrm{CO}_{3}$, and $\mathrm{Ag}_{2} \mathrm{O}$. Our investigation results have also shown that the $\gamma$ $\mathrm{Al}_{2} \mathrm{O}_{3}$-Ag nanopowders exhibit large specific surface area and good antimicrobial properties $[14,15]$.

\section{Conclusions}

Ionic silver $\left(\mathrm{Ag}^{+}\right)$, silver monoxide $\left(\mathrm{Ag}_{2} \mathrm{O}\right)$, and metallic silver $(\mathrm{Ag})$ were incorporated onto an aluminum oxide nanopowder carrier by using subsequent stages of dry solgel method. The $\mathrm{Al}_{2} \mathrm{O}_{3}$ nanopowders added with $\mathrm{Ag}^{+}, \mathrm{Ag}_{2} \mathrm{O}$ and $\mathrm{Ag}$ differed considerably from one another in terms of their morphology, physical, and biocidal properties. Since the work of Xiu et al. [20], it has been generally accepted that the catalytically bactericidal effect of silver nanoparticles comes from a synergic action of reactive oxygen species as a result of $\mathrm{Ag}^{+}$ions release, not however from single $\mathrm{Ag}$ nanoparticles. Thus, it is strongly recommended that the morphostructural aspects of the synthesized nanopowders should be discussed 


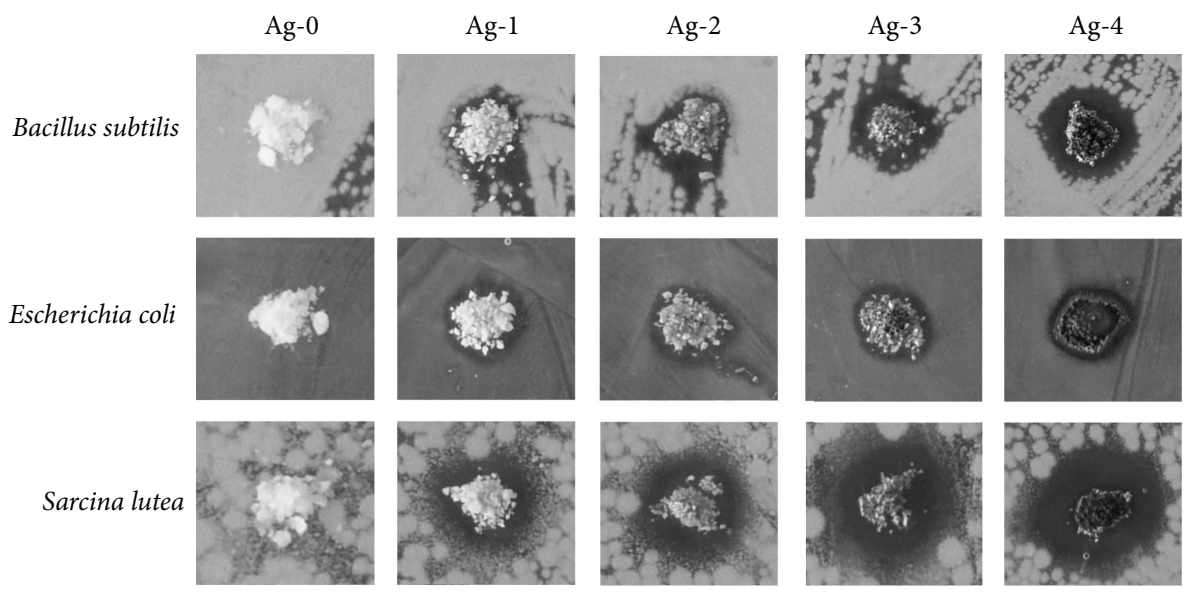

(a)
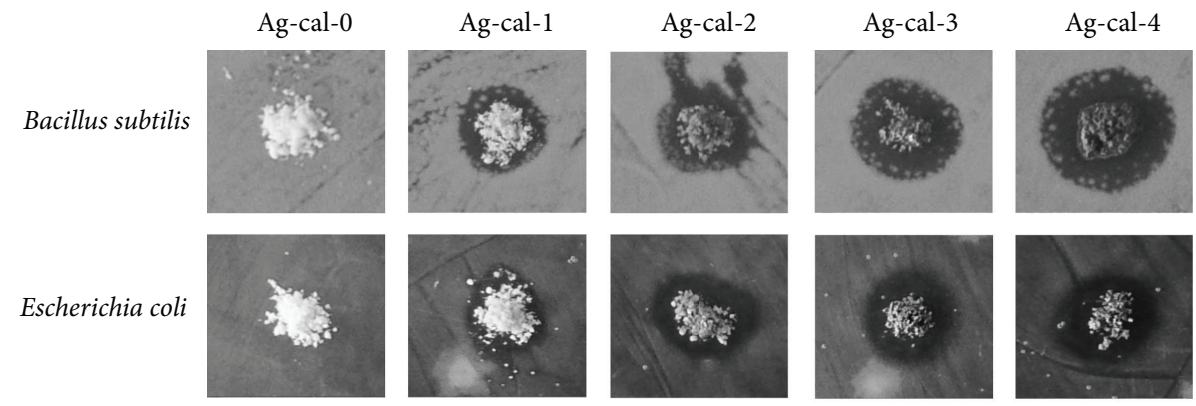

Sarcina lutea
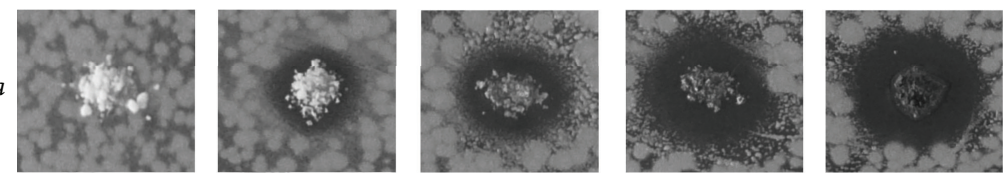

(b)
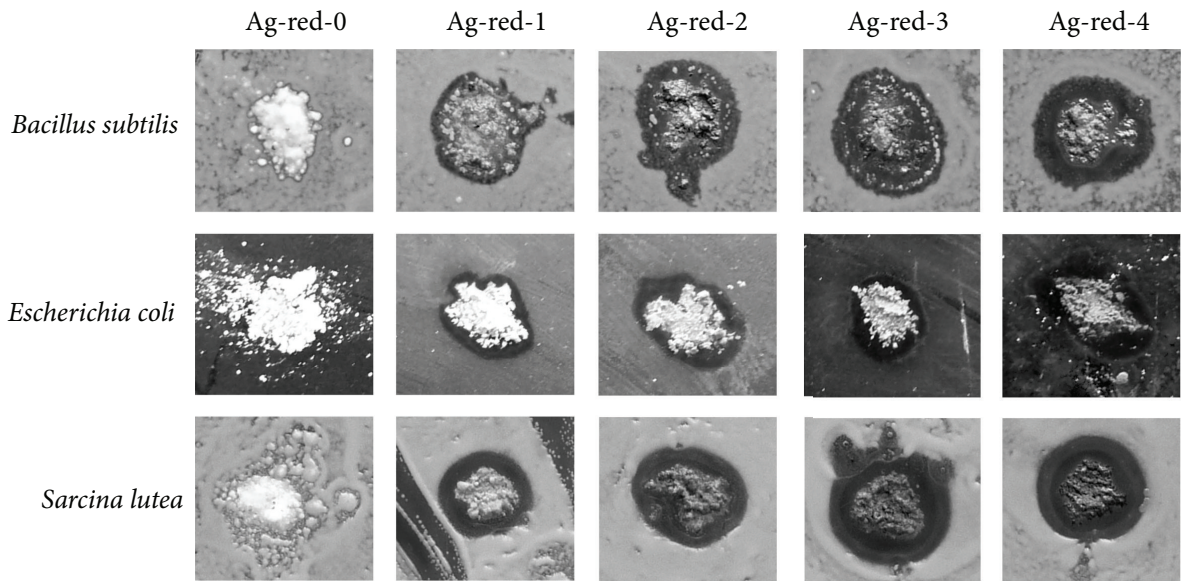

(c)

Figure 6: Photographs of the selected parts of Petri plates covered with nanopowders such as $\mathrm{Al}_{2} \mathrm{O}_{3}-\mathrm{Ag}^{+}(\mathrm{a}), \mathrm{Al}_{2} \mathrm{O}_{3}-\mathrm{Ag}_{2} \mathrm{O}$ (b), and $\mathrm{Al}_{2} \mathrm{O}_{3}-\mathrm{Ag}$ (c) produced by using consecutive stages of the dry sol-gel method after $72 \mathrm{~h}$ incubation. The silver content in the final product was $0.0 \mathrm{wt} \%$ (samples marked with 0), $0.30 \mathrm{wt} \%$ (samples marked with 1), $1.35 \mathrm{wt} \%$ (samples marked with 2), $2.84 \mathrm{wt} \%$ (samples marked with 3), and $12.55 \mathrm{wt} \%$ (samples marked with 4 ). 
TABle 3: Physical properties of the $\mathrm{Al}_{2} \mathrm{O}_{3}-\mathrm{Ag}^{+}, \mathrm{Al}_{2} \mathrm{O}_{3}-\mathrm{Ag}_{2} \mathrm{O}$, and $\mathrm{Al}_{2} \mathrm{O}_{3}-\mathrm{Ag}$ nanopowders produced by the thermal decomposition $\left(700^{\circ} \mathrm{C}\right.$, $24 \mathrm{~h})$ followed by reduction $\left(\mathrm{H}_{2}, 700^{\circ} \mathrm{C}, 2 \mathrm{~h}\right)$.

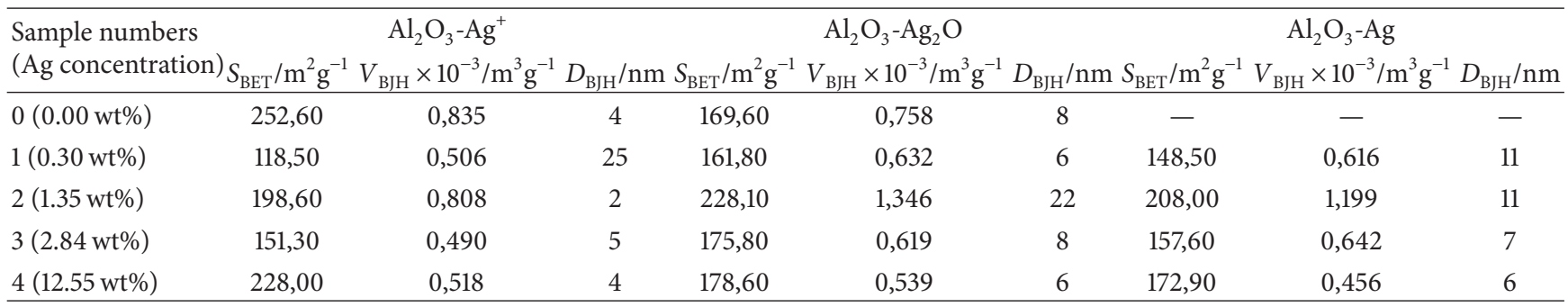
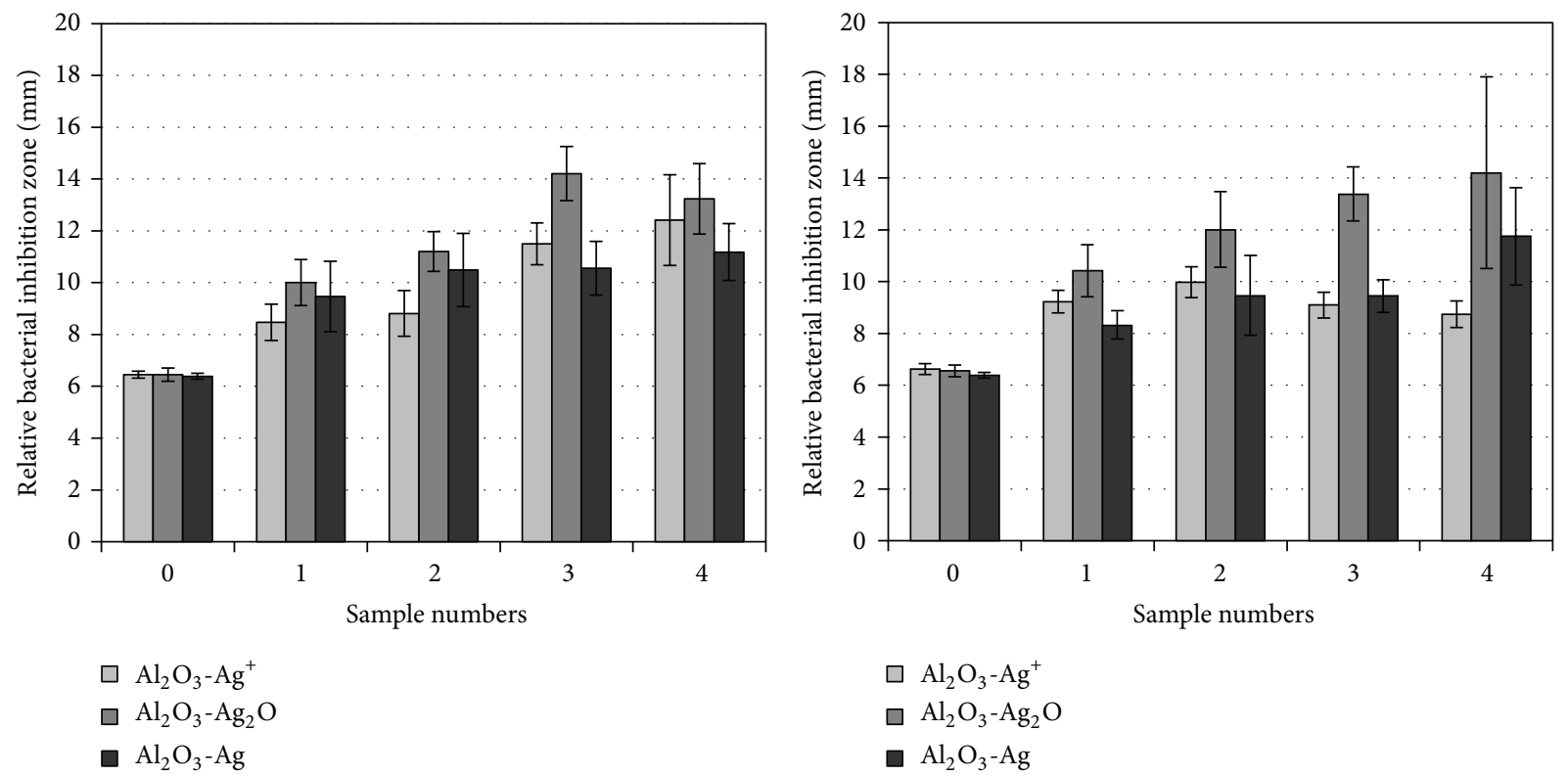

(a)

(b)

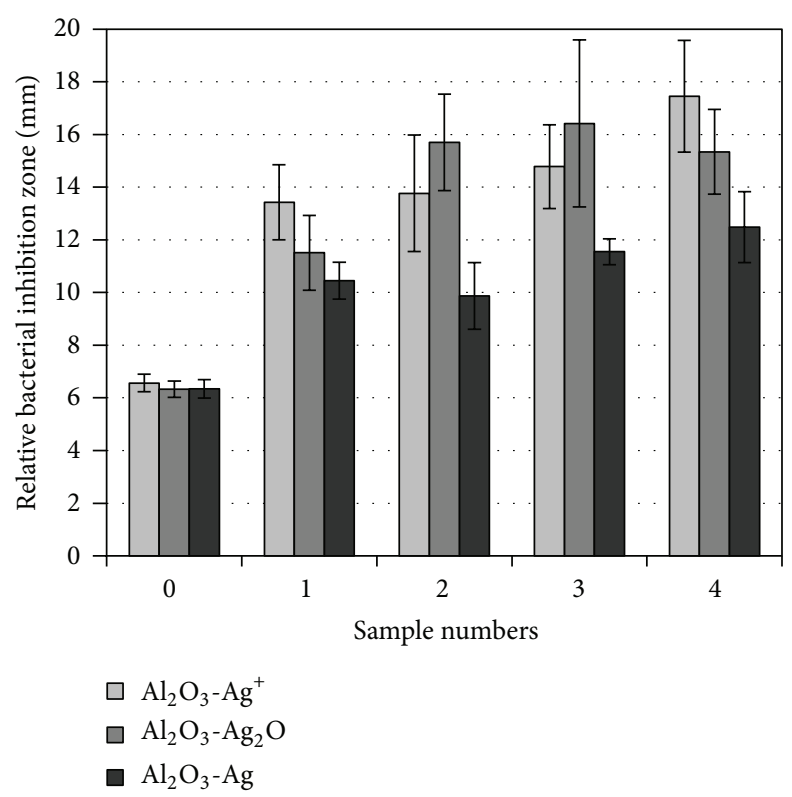

(c)

FIGURE 7: Quantitative results of a growth test method of the bacterial strains such as Bacillus subtilis (a), Escherichia coli (b) and Sarcina lutea (c). The silver content in the final product was $0.0 \mathrm{wt} \%$ (samples marked with 0 ), $0.30 \mathrm{wt} \%$ (samples marked with 1 ), $1.35 \mathrm{wt} \%$ (samples marked with 2), $2.84 \mathrm{wt} \%$ (samples marked with 3), and $12.55 \mathrm{wt} \%$ (samples marked with 4). 
with respect to the possible enhancement of the $\mathrm{Ag}^{+}$ions release. Also other scientific groups results suggest that that silver nanoparticles could undergo a shape-dependent interaction with bacteria. For example, the presence of a \{111\} plane in crystalline lattice combine to promote Ag nanoparticles biocidal property due to the enhancement of $\mathrm{Ag}^{+}$ions release [18].

To our knowledge, this is the first comparative study on the bactericidal properties of ionic silver $\left(\mathrm{Ag}^{+}\right)$, silver monoxide $\left(\mathrm{Ag}_{2} \mathrm{O}\right)$, and metallic silver (Ag) incorporated onto an aluminum oxide nanopowder carrier characterized by different morphostructural properties and agglomeration tendency. Nanopowders of $\mathrm{Al}_{2} \mathrm{O}_{3}-\mathrm{Ag}^{+}$were not much less agglomerated with the average agglomerate sizes below $340 \mathrm{~nm}$. The $\mathrm{Al}_{2} \mathrm{O}_{3}$ nanopowder also had very large specific surface area (above $250 \mathrm{~m}^{2} \mathrm{~g}^{-1}$ ) which was evidence that it was highly amorphous and that the possible agglomerates had a very loose structure. This could probably enable better ability of $\mathrm{Ag}^{+}$ions release ability. The $\mathrm{Al}_{2} \mathrm{O}_{3}$ nanopowders added with $\mathrm{Ag}_{2} \mathrm{O}$ were not also much agglomerated with average particles below $38 \mathrm{~nm}$ and agglomerates below $370 \mathrm{~nm}$. It was only with the $\mathrm{Al}_{2} \mathrm{O}_{3}$ - $\mathrm{Ag}$ nanopowders when the $\mathrm{Ag}$ effect (higher Ag nanoparticles addition) becomes highly disadvantageous: the particle size increased from $310 \mathrm{~nm}$ to $962 \mathrm{~nm}$ with increasing Ag content from 0.30 to $12.55 \mathrm{wt} \%$.

The best antibacterial properties against Sarcina lutea strain were achieved in the $\mathrm{Al}_{2} \mathrm{O}_{3}$ nanopowders added with $\mathrm{Ag}^{+}$and $\mathrm{Ag}_{2} \mathrm{O}$ probably due to the fact that these samples were less agglomerated in comparison with $\mathrm{Al}_{2} \mathrm{O}_{3}$ $\mathrm{Ag}$, and their morphostructure could enhance $\mathrm{Ag}^{+}$ions release. Surprisingly, the observed increase of the bactericidal activity as the silver content was increased from 2.84 to $12.55 \mathrm{wt} \%$ was not however significant for all of the synthesized nanopowders. Also Choi et al. [19] described ionic form of silver as being much more effective in bacteria killing in comparison with silver nanoparticles. Their work was not however devoted to investigations of nanoparticles agglomeration tendency.

Our results demonstrate that the worst effect against Escherichia coli and Sarcina lutea was shown by the $\mathrm{Al}_{2} \mathrm{O}_{3}$ $\mathrm{Ag}^{+}$and $\mathrm{Al}_{2} \mathrm{O}_{3}-\mathrm{Ag}$ nanopowders, respectively. Moreover, the increase in bactericidal activity was not significant with increasing Ag content from 0.30 to $12.55 \mathrm{wt} \%$.

The results obtained in the present experiments show that the $\mathrm{Al}_{2} \mathrm{O}_{3}$ nanopowder added with $\mathrm{Ag}_{2} \mathrm{O}$ produced by the sol-gel method is considered as the best raw material for the production of biocidal materials. It is, however, worth noting that the dry sol-gel method is much more "clean" from the chemical point of view, since during this process, apart from carbon dioxide, no other undesired side products appear which could be harmful to the environment.

\section{Conflict of Interests}

The paper contains all information regarding equipment and chemicals used for measurements such as X-ray diffractometer (Philips), scanning electron microscope (Zeiss), Quadrasorb-SI device (Quantachrome Co.), and chemicals
(Merck). X-ray diffractometer and Quadrasorb-SI device are the property of Warsaw University of Technology. Scanning electron microscope is the property of the Institute of High Pressure Physics of Polish Academy of Sciences; however, there is no conflict of interests because all the measurements were paid for. Thus, there is no conflict of interests regarding our investigations. Chemicals used for the study were also purchased from Merck and there is no conflict of interests to declare.

\section{Acknowledgments}

The study was accomplished thanks to the funds allotted by the European Union within the framework of the project entitled "Program for the Development of the Warsaw University of Technology" financed by the European Social Funds and the National Budget and also thanks to the funds allotted by the Ministry of Science and Higher Education within the framework of the research project no. N N507 469538.

\section{References}

[1] S. Pal, Y. K. Tak, and J. M. Song, "Does the antibacterial activity of silver nanoparticles depend on the shape of the nanoparticle? A study of the gram-negative bacterium Escherichia coli," Applied and Environmental Microbiology, vol. 73, no. 6, pp. 17121720, 2007.

[2] M. J. Pike-Biegunski, "Nanotechnology in medicine and pharmacy-part 2," Drug in Poland, vol. 15, no. 10(208), pp. 49$56,2005$.

[3] K. Kalishwaralal, S. BarathManiKanth, S. R. K. Pandian, V. Deepak, and S. Gurunathan, "Silver nano-a trove for retinal therapies," Journal of Controlled Release, vol. 145, no. 2, pp. 7690, 2010.

[4] Q. Chang, H. He, and Z. Ma, "Efficient disinfection of Escherichia coli in water by silver loaded alumina," Journal of Inorganic Biochemistry, vol. 102, no. 9, pp. 1736-1742, 2008.

[5] E. Verné, S. Ferraris, M. Miola et al., "Synthesis and characterisation of bioactive and antibacterial glass-ceramic-part 1 : microstructure, properties and biological behaviour," Advances in Applied Ceramics, vol. 107, no. 5, pp. 234-244, 2008.

[6] S. Tripathi, G. K. Mehrotra, and P. K. Dutta, "Chitosansilver oxide nanocomposite film: preparation and antimicrobial activity," Bulletin of Materials Science, vol. 34, no. 1, pp. 29-35, 2011.

[7] J. J. Buckley, P. L. Gai, A. F. Lee, L. Olivi, and K. Wilson, "Silver carbonate nanoparticles stabilised over alumina nanoneedles exhibiting potent antibacterial properties," Chemical Communications, no. 34, pp. 4013-4015, 2008.

[8] E. Verné, S. Ferraris, M. Miola et al., "Synthesis and characterisation of bioactive and antibacterial glass-ceramic-part 2: plasma spray coatings on metallic substrates," Advances in Applied Ceramics, vol. 107, no. 5, pp. 245-253, 2008.

[9] V. A. Dubok, "Bioceramics-yesterday, today, tomorrow," Powder Metallurgy and Metal Ceramics, vol. 39, no. 7-8, pp. 381-394, 2000.

[10] E. Weir, A. Lawlor, A. Whelan, and F. Regan, "The use of nanoparticles in anti-microbial materials and their characterization," Analyst, vol. 133, no. 7, pp. 835-845, 2008. 
[11] G. Wang, C. Shi, N. Zhao, and X. Du, "Synthesis and characterization of $\mathrm{Ag}$ nanoparticles assembled in ordered array pores of porous anodic alumina by chemical deposition," Materials Letters, vol. 61, no. 18, pp. 3795-3797, 2007.

[12] A. Esteban-Cubillo, C. Díaz, A. Fernández et al., "Silver nanoparticles supported on $\alpha$-, $\eta$ - and $\delta$-alumina," Journal of the European Ceramic Society, vol. 26, no. 1-2, pp. 1-7, 2006.

[13] Q. Chang, H. He, and Z. Ma, "Efficient disinfection of Escherichia coli in water by silver loaded alumina," Journal of Inorganic Biochemistry, vol. 102, no. 9, pp. 1736-1742, 2008.

[14] A. M. Jastrzębska, A. R. Kunicki, A. R. Olszyna, and E. Karwowska, " $\mathrm{Al}_{2} \mathrm{O}_{3}-\mathrm{Ag}$ nanopowders: new method of synthesis, characterisation and biocidal activity," Advances in Applied Ceramics, vol. 110, no. 2, pp. 108-113, 2011.

[15] A. M. Jastrzębska, E. Radziun, M. Roslon et al., "In vitro assessment of antibacterial properties and cytotoxicity of $\mathrm{Al}_{2} \mathrm{O}_{3}-\mathrm{Ag}$ nanopowders," Advances in Applied Ceramics, vol. 110, no. 6, pp. 353-359, 2011.

[16] E. P. Turevskaya, N. Y. Turova, V. G. Kessler, and M. I. Yanovskaya, Eds., The Chemistry of Metal Alkoxides, Kluwer Academic Publishers, Dordrecht, The Netherlands, 2002.

[17] A. W. Bauer, W. M. Kirby, J. C. Sherris, and M. Turck, "Antibiotic susceptibility testing by a standardized single disk method," American Journal of Clinical Pathology, vol. 45, no. 4, pp. 493496, 1966.

[18] S. Pal, Y. K. Tak, and J. M. Song, "Does the antibacterial activity of silver nanoparticles depend on the shape of the nanoparticle? A study of the gram-negative bacterium Escherichia coli," Applied and Environmental Microbiology, vol. 73, no. 6, pp. 17121720, 2007.

[19] O. Choi, K. K. Deng, N.-J. Kim, L. Ross Jr., R. Y. Surampalli, and $\mathrm{Z}$. Hu, "The inhibitory effects of silver nanoparticles, silver ions, and silver chloride colloids on microbial growth," Water Research, vol. 42, no. 12, pp. 3066-3074, 2008.

[20] Z.-M. Xiu, Q.-B. Zhang, H. L. Puppala, V. L. Colvin, and P. J. J. Alvarez, "Negligible particle-specific antibacterial activity of silver nanoparticles," Nano Letters, vol. 12, no. 8, pp. 4271-4275, 2012. 

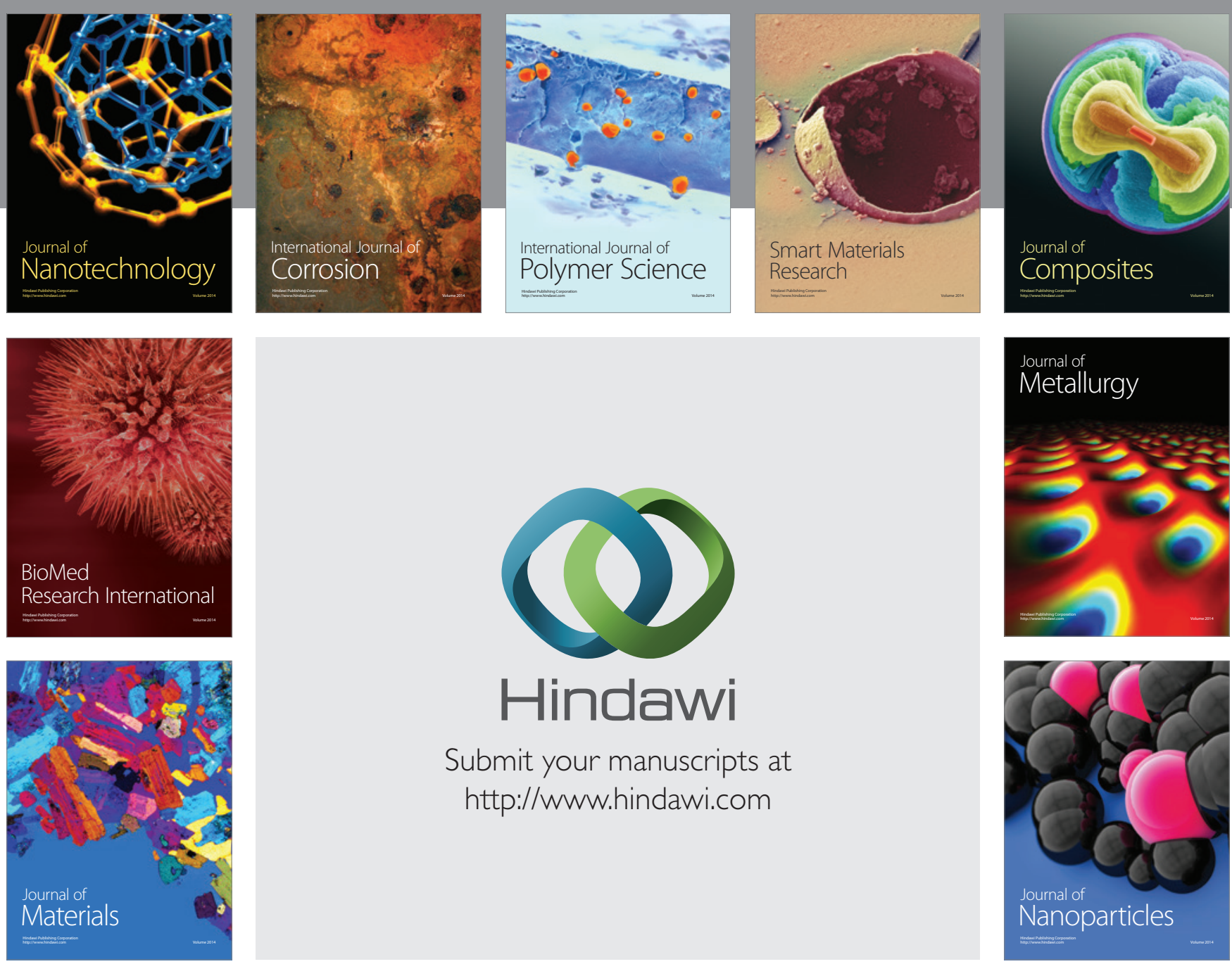

Submit your manuscripts at http://www.hindawi.com
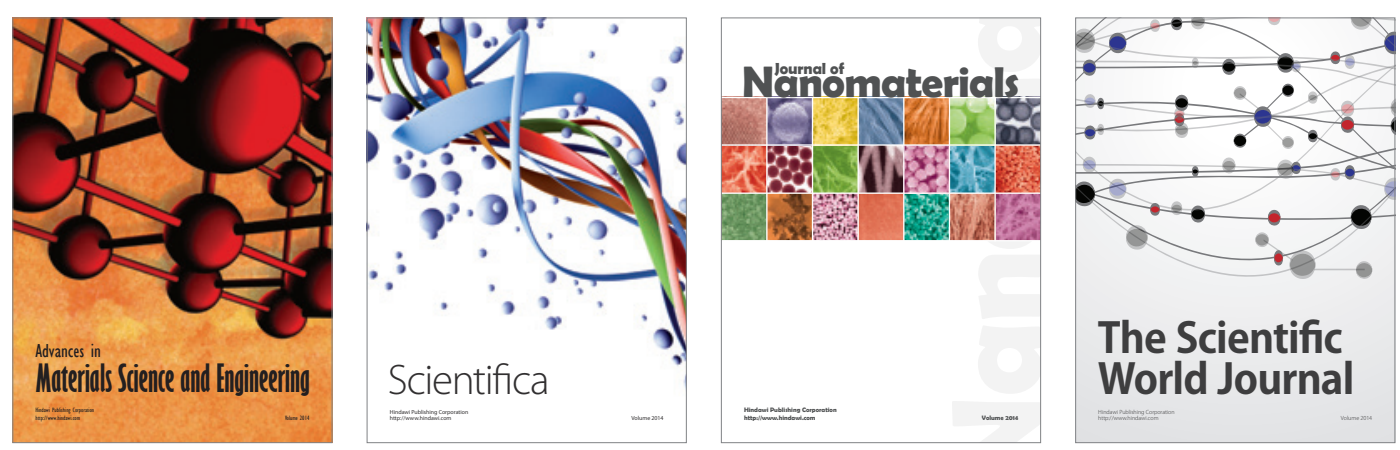

\section{The Scientific World Journal}
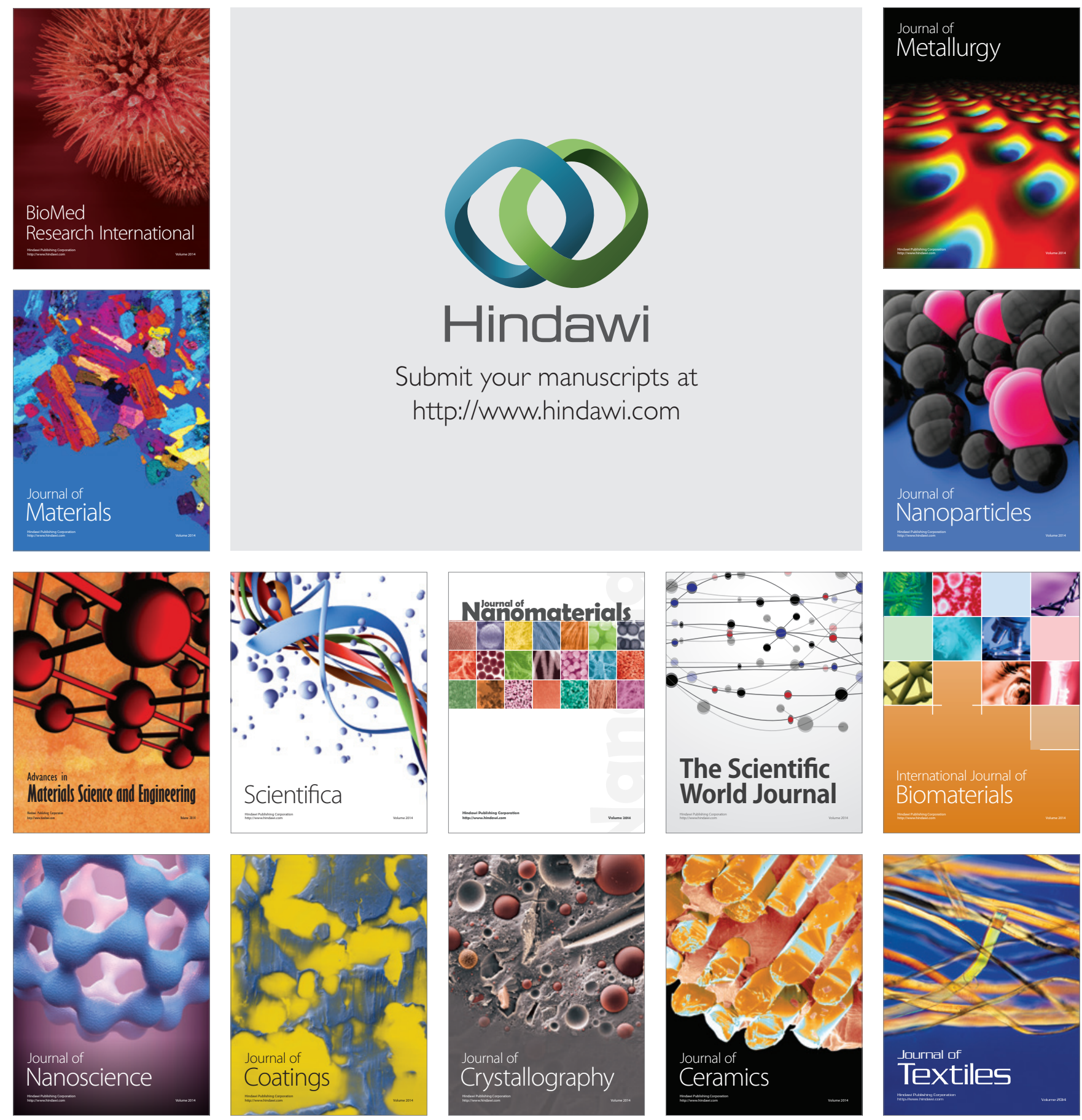